Veterinary College; S. Boyle, Photographic Section, I.C.I. Research Dept. ; Miss K. C. Clark, radiologist, Ilford, Itd. ; G. A. Jones, Research Dept., Kodak, Ltd. ; E. H. Le Mon, Tanar (British) Corporation; Dr. H. Mandiwall, dental surgeon; C. D. Reyersbach, of W. Watson and Son, Ltd.; G. H. Sewell (treasurer), Ministry of Supply ; R. McV. Weston (organizing secretary), Ministry of Supply. Further information can be obtained from the organizing secretary, R. McV. Weston, whose present address is Houndwood, Farley, Salisbury, Wilts.

\section{Committee on Nutrition Surveys}

INVESTIGATION on certain aspects of nutrition is at present handicapped by lack of co-operation. In view of the importance, at the present time, of a thorough knowledge of the state of nutrition in Great Britain, the Nutrition Society has accordingly set up a Committee on Nutrition Surveys, with Sir Joseph Barcroft as chairman; the terms of reference are the co-ordination of nutrition surveys dependent on (a) clinical, physiological and biochemical examinations of human subjects, (b) examinations of food budgets, and $(c)$ chemical analyses of food and meals (including collective meals). It will put investigators in touch with others who are working on the same lines or would co-operate ; it will supply information, recommend methods and make periodical summaries of the results of investigations. The Committee has the support of the Ministries of Health and of Food and co-operation of the Services. Prof. J. R. Marrack has been appointed as a director serving under the Committee. All who are engaged on or undertaking investigations covered by the terms of reference are invited to communicate with Prof. Marrack at the London Hospital, Whitechapel, E.1.

\section{Soviet Medical and Scientific Men}

N. Egorov writes: The Medical Section of the Allunion Society for Cultural Relations with Foreign Countries is strengthening the scientific bonds of Soviet medical circles with medical institutions, organizations and scientific workers in other countries. At the last plenary meeting of this Section it was announced that the Section has received many requests from medical institutes, societies and individual scientific men wishing to establish or revive connexions broken off by the War. The Section has taken steps to make this possible. It has done much to forward abroad books and articles written by members of medical institutes in the U.S.S.R. and to send greetings from Soviet scientific men to various journals and to workers in the field of medicine. The Section has also dealt with numerous requests from Russian men of science for books and articles not available in Moscow to be sent from Great Britain and the United States. To make widely known the work of Soviet medical institutes, clinics and scien. tific workers, the Section regularly publishes the Medical Chronicle, which reflects current war-time problems of Soviet medicine. It has also selected for foreign countries scientific films on various medical subjects such as "Physiology and Morphology of Bacteria", "Microscopic Study of Living Tissue" and "Physiology and Pathology of the Heart", in the production of which eminent Soviet men of science took part. Nicholas Semashko stated that the Section receives publications issued by the Medical Society of America and a War-time Medical Review from Great Britain published by the Anglo-Soviet Com- mittee of Medicine. All this literature is handed over to the Central Medical Library and to libraries of various medical institutes, so that wide use can be made of it. Addresses of members of the Section on the report of Prof. Nicholas Semashko discussed the strengthening of scientific ties with medical organizations and individuals abroad. The Section aims at facilitating the exchange of experience in the medical sciences and increased collaboration of Soviet, British and American medical workers. Nicholas Burdenko, of the Academy of Sciences of the U.S.S.R., was presented at the meeting with a complete set of surgical instruments sent to him from Philadelphia.

\section{Science and Reconstruction in Canada}

IN a paper, "Science and Reconstruction in Canada", read at a joint session of the Royal Society of Canada at the University of Toronto on May 29, 1942, which has now been reprinted, Prof. J. K. Robertson points out that in the industrial and social fields, the federal and provincial governments in Canada have already shown that they are aware of some of the urgent problems which will have to be met when victory comes. Referring to specific ways in which the services of the scientific worker are essential, Prof. Robertson instanced the increased use of Canada's coal deposits, particularly methods of utilizing coal at its source; and the depletion of existing ore reserves and the desirability of discovering new sources of both old and new materials and developing new processes of extraction, for example, for magnesium. After speaking of the utilization of waste materials, such as natural gas, as a field for research, he referred to schemes intended to promote decentralization or dispersal of industry, the industrial utilization of farm products, and a general improvement in living conditions and in methods of farm operation through more available and cheaper power. Although in part economic questions, the practicability of such schemes depends largely on the work of the man of science. Again, in regard to the farm as a source of raw materials, the position of the plastics industry requires consideration in relation to agriculture. The soya bean, for example, is the raw material, not only for oil but also for a new cloth and for a plastic adhesive for plywood, while such materials as straw and cereal refuse might conceivably also find uses in the plastics industry.

Finally, Prof. Robertson considered the relation of science to society, and suggested that science should be more than the handmaid of the State. Science should recognize that it has a social mission and accept a wider responsibility than in the past. Problems involving co-ordination of the sciences, a wiser application of new discoveries, and quicker and better State action following official reports would be helped greatly by the establishment of a small scientific advisory council to act in a liaison capacity between science and government. It would also be of great value in the consideration of the larger social issues which will have to be faced in the post-war years. Scientific men, collectively and individually, must also do more to educate the general public about the nature of their investigations. They gladly recognize that man does not live by bread alone, but they claim that a type of training which insists on honest inquiry, impartial judgment and a fearless facing of all facts is not altogether remote from the other tradition which puts the emphasis on truth, beauty and goodness. 